\title{
Early Childhood Learning Model Based On Local Wisdom Entrepreneurship In Banten Province
}

\author{
Umayah, Muhiyatul Huliyah \\ Received: 21022021 / Accepted: 05062021 / Published online: 30062021 \\ (C) 2021 Association of Indonesian Islamic Early Childhood Education Study Program
}

\begin{abstract}
Abstrak Penelitian ini menggunakan metode penelitian kualitatif deskriptif yang bertujuan untuk mendapatkan informasi tentang pembelajaran anak usia dini berbasis kewirausahaan kearifan lokal. Penelitian ini dilakukan di TK Bona Kota Serang dan RA Daarul Muqimien Kabupaten Tangerang. Hasil penelitian diperoleh data bahwa di TK Bona telah melaksanakan pembelajaran kewirausahaan melalui kegiatan yang disebutnya dengan "hari pasar". Kegiatan lain yang dilakukan di TK Bona dalam rangka mengembangkan kecakapan hidup adalah kegiatan bermalam di pesantren atau "mondok". Di RA Daarul Muqimien model pembelajaran dalam rangka penanaman nilai-nilai kewirausahaan dilakukan melalui kegiatan market day, cooking day, dan fieldtrip. Diharapkan hasil penelitian ini dapat menjadi acuan untuk penelitian selanjutnya dalam mengembangkan model pembelajaran anak usia dini berbasis kewirausahaan budaya lokal.
\end{abstract}

Kata Kunci: model pembelajaran, anak usia dini, kewirausahaan, kearifan lokal, Banten

\begin{abstract}
This study uses descriptive qualitative research methods. The aim of this study was to obtain information about early childhood learning based on local wisdom entrepreneurship. This research was conducted at TK Bona Kota Serang and RA Daarul Muqimien Tangerang Regency. The results obtained in this study show that TK Bona have implemented entrepreneurship learning through "market days" activities. Another activity carried out at TK Bona in order to develop life skills is the overnight activity at a pesantren or "mondok". At RA Daarul Muqimien, the learning model in the context of instilling entrepreneurial values were carried out through market day activities, cooking days, and field trips. It is hoped that the results of this study can become a reference for further research in developing early childhood learning models based on local wisdom entrepreneurship.
\end{abstract}

Keywords: early childhood, learning models, local wisdom, entrepreneurship, Banten

\section{Pendahuluan}

Indonesia kaya akan sumber daya alam, tanah air yang subur, dan budaya yang beraneka ragam. Akan tetapi negara yang kaya raya ini tidak serta merta akan menjadi negara makmur. Menurut David McCelland dalam Nurseto (2010, p.3) bahwa suatu negara akan menjadi makmur apabila mempunyai entrepreneur paling sedikit $2 \%$ dari total jumlah penduduk negara tersebut. Fakta tersebut hendaknya menjadikan bangsa Indonesia harus segera bangkit untuk menjadi negara makmur, salah satu upayanya adalah dengan pendidikan entrepreneur sejak dini. Karena, periode anak merupakan tahap awal kehidupan individu yang akan menentukan sikap, nilai, perilaku, dan kepribadian individu di masa depan (Santrock, 2006, p.8).

Pendidikan anak usia dini menjadi tolak ukur keberhasilan anak dimasa yang akan datang. Untuk itu penting membangun jiwa kewirausahaan sejak anak usia dini. Karena dalam 
membentuk sifat dan mental wirausaha melalui teoritis dan praktek serta memerlukan waktu dan proses yang panjang. Ketika ini diberikan secara berkelanjutan, lambat laun tertanam di mindset anak tentang kewirausahaan (entrepreneurship). Kelak ketika dewasa nanti anak akan terbiasa dengan entrepreneurship, sehingga anak tidak takut dengan resiko yang akan dihadapi. Meskipun pendidikan kewirausahaan dianggap penting diberikan pada anak sejak dini, namun kenyataannya belum banyak diterapkan di lembaga-lembaga pendidikan anak usia dini. Seperti yang dikatakan Huliyah (2019, p.2) anak yang mengenal dunia entrepreneur sejak dini, akan mendapat manfaat lebih untuk bekal masa depan mereka.

Indonesia selain dengan kekayaan sumber daya alam yang subur juga Negara dengan kekayaan budaya yang beraneka ragam. Akan tetapi, saat ini terutama anak usia dini sangat kurang mengenal budayanya sendiri. Ini disebabkan budaya terutama dan kearifan lokal kurang diperkenalkan di lembaga PAUD. Pembelajaran dalam rangka pendidikan kewirausahaan pada anak usia dini bukan berarti anak diajarkan berdagang saja. Lebih dari itu ada penanaman nilainilai kewirausahaan agar anak memiliki jiwa-jiwa wirausaha, seperti sifat sabar, sikap tangguh dan tidak mudah putus asa, percaya diri dan lain-lain serta diharapkan mengenal kearifan lokal dengan melakukan pembelajaran berbasis kewirausahaan kearifan lokal. Di lembaga PAUD tidak ada istilah mata pelajaran, namun terintegrasi dalam pembelajaran tematik dan holistik pada berbagai aspek pengembangan, yaitu: moral dan nilai-nilai agama, fisik-motorik, sosialemosional, bahasa, kognitif, dan seni dan kreativitas. Pembelajaran pun dilaksanakan melalui kegiatan bermain yang menarik, aman, nyaman dan menyenangkan bagi anak, sehingga dapat mengembangkan kecakapan, keterampilan, dan mencintai budaya lokal. Dengan latarbelakang tersebut diatas maka rumusan masalah pada penilitian ini adalah: model pembelajaran anak usia dini berbasis kewirausahaan seperti apakah yang berjalan di lembaga PAUD?, apakah kelemahan dan hambatan model pembelajaran anak usia dini berbasis kewirausahaan?, adakah pelaksanaan model pembelajaran anak usia dini berbasis kewirausahaan kearifan lokal?.

Model pembelajaran pada anak usia dini merupakan pengembangan kurikulum secara kongkrit berupa seperangkat rencana yang berisi sejumlah pengalaman belajar melalui bermain yang diberikan kepada anak usia dini berdasarkan potensi dan tugas perkembangan yang harus dikuasainya dalam rangka pencapaian kompetensi yang dimiliki anak (Sujiono, 2011, p.138). Sedangkan yang dimaksud dengan tugas perkembangan adalah mengembangkan secara holistik (menyeluruh) dan terintegrasi (terpadu) enam aspek perkembangan yang terdiri dari : perkembangan moral dan agama, perkembangan fisik motorik, perkembangan kognitif, perkembangan Bahasa, perkembangan sosial-emosi, dan perkembangan seni dan kreativitas. Huliyah (2020, p.69) mengatakan bahwa kurikulum terpadu adalah kurikulum yang mengintegrasikan seluruh aspek perkembangan anak. Artinya kegiatan pembelajaran harus dapat mengembangkan seluruh aspek perkembangan dan tidak dipisah-pisahkan. Model pembelajaran terdiri dari komponen yang meliputi konsep, tujuan pembelajaran, standar kompetensi dan kompetensi dasar, materi, prosedur, metode, sumber belajar, dan teknik evaluasi (Mulyasa, 2012, p.148). Pada pembelajaran anak usia dini pengembangan model pembelajaran didasarkan pada silabus yang dijabarkan menjadi program semester, rencana kegiatan mingguan, dan rencana kegiatan harian.

Kewirausahaan pada penelitian ini mengutip pendapat Drucker 1994 dalam Suryana\&Bayu (2011, p. 24) yang menyatakan bahwa kewirausahaan lebih merujuk pada sifat, watak, dan ciri-ciri yang melekat pada seseorang yang mempunyai kemauan keras untuk mewujudkan gagasan inovatif ke dalam dunia usaha yang nyata dan dapat mengembangkan prinsip kemandirian, keberanian, optimis dan kreativitas dalam menjalankan sebuah usaha. Sementara menurut Ciputra (2009) dalam Huliyah (2019, p.5) terdapat sembilan pilar karakter nilai-nilai luhur universal dari dari entrepreneurship yang ditanamkan kepada anak-anak usia dini, yaitu : (1) karakter cinta Tuhan dan segenap ciptaan-Nya, (2) kemandirian dan tanggung jawab,(3) kejujuran, amanah dan diplomatis, (4) Hormat dan Santun, (5) Dermawan sula menolong, dan gotong royong/kerjasama, (6) percaya diri dan pekerja keras, (7) kepemimpinan dan keadilan, (8) baik dan rendah hati, serta (9) karakter toleransi, kedamaian, dan kesatuan. 
Entrepreneurship adalah sebuah semangat juang mempertahankan hidup, mengembangkan kreasi dan daya inovasi, serta berorientasi kepada kemaslahatan umat manusia dan makhluk hidup lainnya di muka bumi. Dalam rangka mempersiapkan anak-anak untuk menjadi entrepreneur diperlukan suatu usaha dan menyesuaikan dengan karakteristik perkembangan anak. Usaha yang dapat dilakukan oleh pendidik dan orang tua antara lain dijelaskan oleh Soemanto (2008, p.114), yaitu dengan kegiatan bermain dan permainan. Sesuai dengan karakteristik anak usia dini yang tidak akan lepas dari dunia bermain, maka kegiatan pembelajaran berbasis kewirausahaan pada anak usia dini dilakukan secara bermain. Karena bermain memungkinkan anak mengembangkan daya imajinasi anak. Hal ini akan berimplikasi terhadap daya kreativitas anak pada masa perkembangan selanjutnya. Bermain dan permainan yang disiapkan dalam rangka penanaman jiwa kewirausahaan harus dapat mengoptimalkan seluruh panca indera, anak bergerak aktif, menyenangkan, membebaskan anak untuk bereksplorasi, dan lain sebagainya.

Menurut Koentjoroningrat dalam Rahmawati yang dikutip Umayah dan Huliyah (2020, p. 23-24) budaya adalah semua sistem ide, gagasan, rasa, tindakan, serta karya yang dihasilkan oleh manusia dalam kehidupan masyarakat yang nantinya akan dijadikan klaim manusia dengan cara belajar. Menyadari kebudayaan Indonesia yang multi-etnis, selanjutnya GBHN (1993) menegaskan budaya lokal sebagai berikut: kata "lokal" dalam kalimat "budaya lokal" secara tidak langsung telah menunjukkan batasan asal atau tempat keberlakuannya. Namun petunjuk batasan wilayah tersebut dapat bersifat relatif. Apabila yang dimaksud wilayah adalah Asia Tenggara, maka posisi bagian yang ada di dalamnya (misalnya Indonesia) disebut lokal. Sementara bila yang dimaksud wilayahnya itu Indonesia, maka bagian-bagian yang ada di dalamnya (misalnya Jawa Timur) disebut lokal. Mengingat pengertian lokal dapat bersifat relatif, maka perlu ditegaskan bahwa dalam hal ini yang dimaksud budaya lokal adalah budaya yang berlaku pada masyarakat Banten. Selanjutnya budaya lokal menghasilkan Kearifan Lokal. Menurut Rapana (2016, p. 15) kearifan lokal adalah suatu bentuk warisan budaya Indonesia yang telah berkembang sejak lama. Lebih lanjut Rapanna (2016, p.16) menyatakan kearifan lokal lahir dari pemikiran dan nilai yang diyakini suatu masyarakat alam dan lingkungannya. Kearifan lokal mengandung nilai-nilai, norma-norma, sistem kepercayaan dan ide-ide masyarakat setempat. Hal ini menyebabkan kearifan di setiap daerah berbeda-beda. Samudra (2010) dalam Rapanna (2016, p. 32) mengartikan bahwa kearifan lokal sebagai gagasangagasan setempat (lokal) yang bersifat bijaksana, penuh kearifan, bernilai baik, yang tertanam dan diikuti oleh anggota masyarakatnya.

\section{Metode}

Penelitian ini menggunakan metode kualitatif. Sugiyono (2017, p. 9-10) mengatakan metode kualitatif adalah metode penelitian yang berlandaskan pada filsafat postpositivisme, di gunakan untuk meneliti pada kondisi obyek yang alamiah, dimana peneliti adalah sebagai instrument kunci, dan pengambilan sampel sumber data dilakukan secara purposive dan snowbaal. Teknik pengumpulan data pada penelitian ini dilakukan secara triangulasi (gabungan), sementara analisis data bersifat induktif/kualitatif, dan hasil penelitian lebih menekankan makna dari pada generalisasi untuk menemukan hipotesis.

Tahap pertama dalam penelitian ini berangkat dari keingin tahuan tentang pelaksanaan pembelajaran kewirausahaan yang ada di TK/RA. Berdasarkan hal tersebut peneliti kemudian menetapkan fokus dan membuat rumusan masalah berupa pertanyaan penelitian untuk menjawab tujuan penelitian. Langkah ke dua dalam penelitian ini adalah melakukan kajian teori, aturan, budaya, dan kegiatan pembelajaran yang terdapat di TK/RA. Langkah ke tiga adalah peneliti masuk obyek yang diteliti. Sumber data diambil secara purposive dan snowball. Langkah ke empat yang dilakukan peneliti adalah mengumpulkan data. Teknik pengumpulan data dilakukan dengan cara observasi, wawancara mendalam dan peneliti ikut berpartisispasi pada obyek yang diteliti.

Langkah ke lima yang dilakukan peneliti dalam penelitian ini adalah analisisi data. Analisis data adalah prose memilih, memilah dan mengorganisasikan data yang terkumpul dari 
catatan lapangan, hasil observasi, wawancara mendalam dan dokumentasi, sehingga diperoleh pemahaman yang mendalam, bermakna, unik dan berupa temuan baru yang bersifat deskriptif. Dilanjutkan dengan langkah ke enam yaitu pengujian kredibilitas data atau kepercayaan terhadap data hasil penelitian ini dilakukan dengan: (1) perpanjangan pengamatan, pengamatan pada awalnya dilakukan pada bulan Maret 2020, kemudian karena terkendala oleh pandemi Covid dan berdasarkan SKB tiga Menteri kegiatan pembelajaran di ditingkatan PAUD/TK/RA dilakukan secara on line yaitu melalui kegiatan belajar dari rumah (BDR) maka penelitian di TK Bona dilanjutkan pada bulan September 2020 untuk melengkapi data. Adapun untuk RA Daarul Muqimien penelitian dilakukan pada bulan Maret - April 2020. (2) Peningkatan ketekunan dalam penelitian dilakukan dengan semakin intens mendatangi TK tersebut untuk melakukan pengamatan secara lebih cermat dan berkesinambungan; (3) Melakukan triangulasi untuk memperoleh data yang ajeg; (4) Diskusi dengan teman sejawat tentang model pembelajaran berbasis kewirausahaan untuk anak usia dini; (5) Kegiatan menganalisis data negatif, artinya peneliti mencari data yang berbeda atau bertentangan; (6) kemudian melakukan member check untuk mendapatkan kesesuaian data yang diperoleh dari pemberi data.

\section{Hasil Penelitian}

Penelitian ini merupakan penelitian kualitatif deskriptif yang dilaksanakan di dua lembaga yaitu TK Bona Kota Serang dan RA Daarul Muqimien Buaran Jati Sukadiri Tangerang.

\section{TK Bona}

TK Bona berlokasi di Taman Widya Asri Blok E.1 No.9, Kecamatan Serang, Kota Serang Provinsi Banten, dengan kepala sekolah ibu Elida Ayunawati, S.Pd. TK Bona berdiri tahun 2004 dengan izin operasional 642.1/sk.2098-Dis.Pend. dan nomor NPSN 69753776. TK Bona saat ini belum terakriditasi, terdiri dari 1 orang tenaga kependidikan, dan 10 orang tenaga pendidik. Adapun jumlah murid tahun ajaran 2019/2020 sebanyak 73 anak. TK Bona memiliki visi yaitu "menjadi lembaga PAUD pelopor yang mampu melahirkan yang memiliki kecerdasan intelektual, kecerdasan emosional, dan kecerdasan spritual", dengan misi lembaga sebagai berikut:

1. Mengembangkan dengan pembelajaran yang menyenangkan dan bermakna yang dapat mestimulasi kecerdasan majemuk anak

2. Mengembangkan dengan pembelajaran yang dapat mengembangkan konsep diri dan lingkungan

3. Mengembangkan melalui pembelajaran, pembiasaaan dan teladan yang terintegrasi dalam seluruh aspek perkembangan sehingga akan mampu mencintai dengan ridho cinta-Nya.

Dengan visi dan misi tersebut, TK Bona memiliki kekhasan kaitannya dengan penanaman nilai-nilai kewirausahaan, yaitu dengan adanya kegiatan yang disebutnya "Hari Pasar". Hari Pasar merupakan hari di mana anak belajar jual beli dalam rangka penanaman jiwa kewirausahaan. Kegiatan hari pasar ini dilakukan hari rabu setiap dua minggu sekali dengan membagi satu kelas bertugas untuk menjual, dan kelas lainnya sebagai pembeli. Adapun yang dijual adalah makanan yang dibuat atau dipersiapkan orang tua/ibu bersama anak di rumah. Setiap makanan yang diperjual belikan berkisar antara Rp.1000,00 - 2000,00. Pembayaran dilakukan dengan menggunakan uang-uangan yang dibuat berbentuk kartu kertas yang dipersiapkan guru, yang bernilai Rp.1000,00 tiap lembarnya. Sebelumnya anak menukar uang rupiah dengan uang-uangan tersebut. Dalam kegiatan ini tidak hanya sekedar jual-beli anak juga diajarkan untuk komunikasi dengan mempromosikan jualannya. 

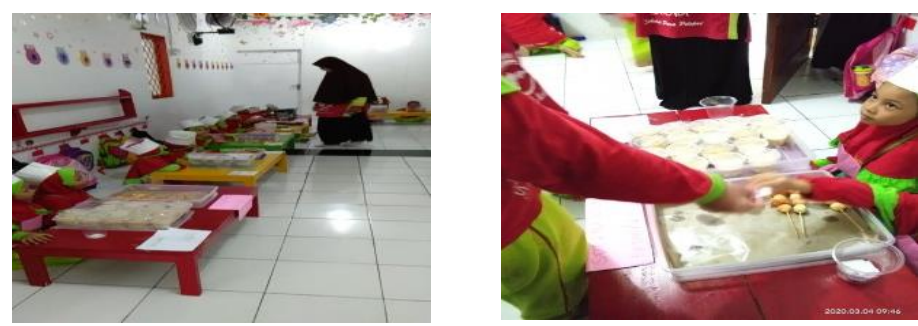

Gambar 1. Kegiatan Hari Pasar di TK Bona

Tujuan kegiatan hari pasar di TK Bona adalah menanamkan kewirausaahan dalam rangka mengembangkan kecakapan hidup. Seperti yang terdapat dalam misi TK Bona yaitu mengembangkan konsep diri dan lingkungan. Tidak hanya hari pasar TK Bona juga menyelanggarakan kegiatan yang dinamakan "hari santri", yaitu kegiatan bermalam di pesantren (mondok) yang ada di sekitar TK Bona. Kegiatan ini merupakan salah satu upaya sekolah agar anak mandiri berbasis kearifan lokal dan mengenalkan pesantren. Karena salah satu kearifan lokal yang dimiliki kota Serang Banten salah satunya yaitu banyaknya pondokpesantren dan kebiasaan orang tua memasukan anak-anaknya di pesantren untuk mendapatkan ilmu agama Islam. Kegiatan "nyantri" ini dilaksanakan untuk kelas B menjelang kelulusannya. Meskipun bermalam di Pesantren, anak-anak TK B Bona tidak mengikuti pembelajaran pesantren, hanya melihat dan memperkenalkan kegiatan pesantren. Selain itu mereka mengadakan kegiatan sendiri yang dipersiapkan oleh TK Bona, dan kegiatan tersebut dipimpin dan diawasi langsung oleh tenaga pendidik TK Bona.

Dua kegiatan tersebut menurut ibu Elida Ayunawati, S.Pd. selaku kepala sekolah TK Bona merupakan kegiatan untuk menanamkan jiwa kewirausahaan dan kecakapan hidup pada anak usia dini. Kegiatan tersebut juga nampak pada perecanaan pembelajaran Program Tahunan (PROTA), Program Semester (PROSEM), RPPM dan RPPH, akan tetapi belum teramati sesuai dengan tema ataupun sub tema pertemuan minggu tersebut. Dalam salah satu contoh RPPM TK Bona, terdapat kegiatan life skill dengan diisi kegiatan hari pasar, akan tetapi kegiatan tersebut tersebut tidak ada keterkainnya dengan tema pertemuan minggu tersebut. Padahal kegiatan pembelajaran di TK adalah tematik dan dilaksnakan secara holistik dan terintegratif. Berikut adalah salah satu contoh RPPM TK Bona:

Tabel 1. RPPM TK Bona

\begin{tabular}{|c|c|c|c|}
\hline Hari & KD & Materi Pembelajaran & Rencana Kegiatan \\
\hline & 1.1 & - Aku ciptaan Allah SWT & Pembiasaan: \\
\hline & & - Menghargai diri sendiri, orang & - Mengucap salam \\
\hline & 1.2 & lain dan lingkungan & Absen \\
\hline & & - Memiliki perilaku & Tilawati \& membaca \\
\hline & 2.13 & mencerminkan sikap jujur & - Menggambar/menulis \\
\hline & 2.1 & $\begin{array}{l}\text { - Memiliki perilaku yang } \\
\text { mencerminkan hidup sehat }\end{array}$ & - $\begin{array}{ll}\text { Bermain } \\
\text { - } & \text { Berbaris dan berdoa }\end{array}$ \\
\hline & $3.2-4.2$ & $\begin{array}{l}\text { - Memiliki perilaku baik dan } \\
\text { santun sebagai cerminan akhlak } \\
\text { mulia }\end{array}$ & $\begin{array}{ll} & \text { bersama } \\
\text { - } & \text { Ice breaking } \\
\text { - } & \text { Murojaah }\end{array}$ \\
\hline \multirow{3}{*}{ Senin } & 3.3-4.3 & - Mengenal anggota tubuh, fungsi & \multirow{3}{*}{$\begin{array}{l}\text { Kegiatan tema: } \\
\text { Pembelajaran iman: membuat } \\
\text { tumbuhan atau pohon, pelaksanaan } \\
\text { kegiatan dengan tahap-tahap } \\
\text { (mengamati, menanya) menonton } \\
\text { animasi dan tanya jawab. }\end{array}$} \\
\hline & 2.7 & pengembangan motorik kasar & \\
\hline & $\begin{array}{l}3.11- \\
4.11 \\
3.10-\end{array}$ & $\begin{array}{l}\text { dan halus } \\
\text { - Memiliki perilaku yang } \\
\text { mencerminkan sikap sabar } \\
\text { - Mengungkapkan perasaan, ide }\end{array}$ & \\
\hline
\end{tabular}




\begin{tabular}{|c|c|c|c|}
\hline \multirow[t]{2}{*}{ 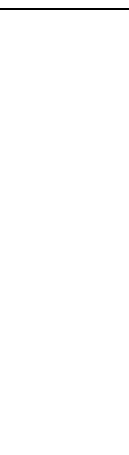 } & \multirow[t]{2}{*}{2.6} & dengan pilihan kata yang sesuai & \multirow[b]{2}{*}{$\begin{array}{l}\text { Keaksaraan: } \\
\text { Pelaksanaan kegiatan dengan } \\
\text { tahap-tahap mengamati, menanya, } \\
\text { mengumpulkan informasi. } \\
\text { Raga main: menarik bola warna } \\
\text { dengan gambar pelangi, meronce } \\
\text { dan menyusun. }\end{array}$} \\
\hline & & $\begin{array}{l}\text { ketika berkomunikasi dan } \\
\text { menceritakan kembali isi cerita } \\
\text { sederhana } \\
\text { - Memahami bahasa (menyimak } \\
\text { dan membaca) dan } \\
\text { menunjukkan kemampuan } \\
\text { bahasa } \\
\text { - Memahami aturan dalam satu } \\
\text { permainan }\end{array}$ & \\
\hline Selasa & $\begin{array}{l}3.15- \\
4.15\end{array}$ & - Mengenal berbagai karya seni & $\begin{array}{l}\text { Seni: } \\
\text { Membuat karya seni pohon }\end{array}$ \\
\hline Rabu & $3.4-4.4$ & $\begin{array}{l}\text { - Memiliki perilaku yang } \\
\text { mencerminkan hidup sehat }\end{array}$ & $\begin{array}{l}\text { Discovery: } \\
\text { Life skil (kewirausahaan) }\end{array}$ \\
\hline Kamis & $3.6-4.6$ & 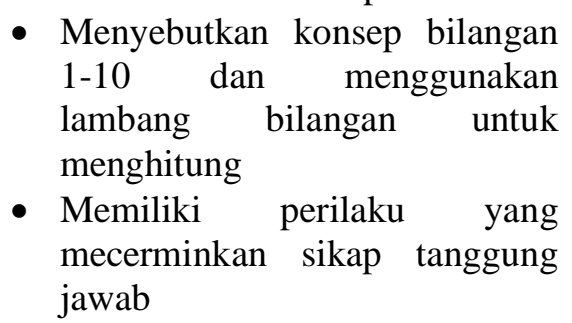 & $\begin{array}{l}\text { Matematika: } \\
\text { mengenal konsep bilangan 1-10 }\end{array}$ \\
\hline Jumat & $\begin{array}{l}3.2-4,2 \\
3.1-4.1\end{array}$ & $\begin{array}{l}\text { - Mengenal perilaku akhlak mulia } \\
\text { - Mengenal kegiatan beribadah } \\
\text { sehari-hari }\end{array}$ & $\begin{array}{l}\text { Listerasi: } \\
\text { Mendengarkan cerita, menonton } \\
\text { adab dan melaksanakan sholat } \\
\text { dhuha }\end{array}$ \\
\hline
\end{tabular}

\section{RA Daarul Muqimien}

Raudhathul Athfal (RA) Daarul Muqimien berlokasi di Desa Buaran Jati Kecamatan Sukadiri Kabupaten Tangerang. RA ini dikepalai oleh ibu Eli Rosita, S.Pd.I dengan jumlah pendidik sebanyak 5 orang, dan jumlah murid 58 anak. RA Daarul Muqimien memiliki visi "Menjadi Raudhatul Athfal yang mampu mencetak generasi anak muslim yang cerdas, terampil, mandiri, dan berkarakter". Dengan misi sebagai berikut:

1. Membentuk perkembangan kepribadian dan akhlak anak

2. Menanamkan kemandirian kepada anakk

3. Mengembangkan kemampuan berkomunikasi dan bersosialisasi

4. Menyiapkan anak yang bermental seorang usahawan

5. Membekali anak untuk memasuki jenjang pendidikan tingkat selanjutnya

Salah satu misi yang di usung oleh RA Daarul Muqimien yang terdapat pada point 4 adalah menyiapkan anak yang bermental seorang usahawan. Misi tersebut diwujudkan dalam bentuk kegiatan market day, cooking day, dan field trip sesuai tema pembelajaran pada minggu tersebut. Seperti yang dikatakan oleh pengurus yayasan ibu Iswarniza, S.Pd. bahwa makna misi tersebut bukan hanya sekedar mengajarkan berjualan akan tetapi lebih menekankan pada mental menjadi wirausaha, yaitu mental tangguh, percaya diri dan kreatif. Berbeda dengan pendidikan tingkat menengah atau perguruan tinggi, di RA Daarul Muqimien penanaman mental usahawan ini terintegrasi dengan kegiatan dalam rangka mengembangkan tugas perkembangan pada anak usia dini yaitu, aspek perkembangan moral dan agama, fisik-motori, kognitif, Bahasa, sosialemosi dan seni/kreativitas. Berikut adalah program semester satu RA Daarul Muqimien: 


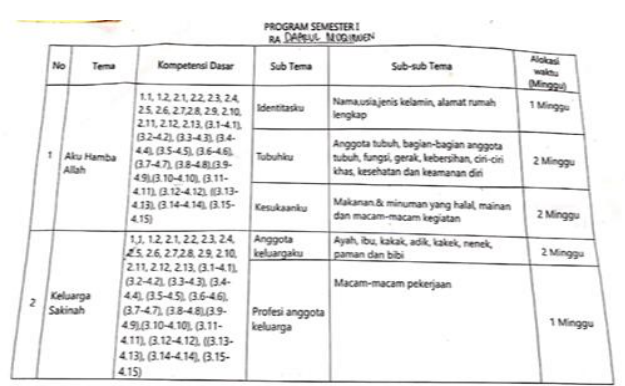

Gambar 2. Program Semester I RA Daarul Muqimien

Kegiatan market day dilaksanakan bersamaan setelah cooking day, yaitu, anak menjual makanan hasil kegiatan cooking day berupa makanan ringan (snack). Hasil cooking day tersebut tersebut di jual ke Kakak-kakak yang bersekolah di MI Daarul Muqimien. Karena yayasan ini terdiri dari RA dan MI Daarul Muqimien. Kegiatan market day yang lain yang dilaksanakan adalah kegiatan mengunjungi mini market yang berada di lingkungan RA Daarul Muqimien. Dengan modal uang sepuluh ribu anak dibiarkan memilih apa yang hendak dibeli dan bertransaksi dengan kasir tanpa ditemani orang tua hanya didampingi guru. Kegiatan lainnya dalam rang ka menanamkan mental wirausaha yaitu field trip menanam padi di sawah yang ada dilingkungan RA, mengunjungi rumah sakit dan menjadi dokter cilik serta mengunjungi stasiun kereta dan naik kereta rel listrik (KRL). (Dokumentasi kegiatan sebelum pandemi covid 2019).

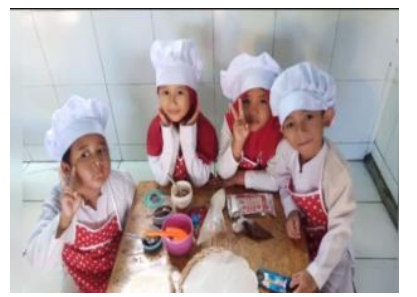

Gambar 3. Kegiatan Cooking day

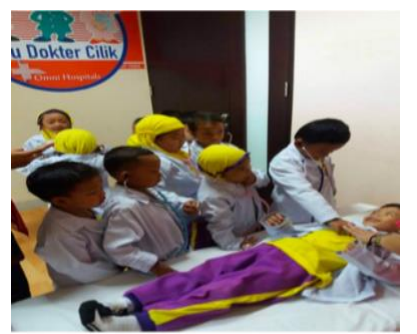

Gambar 5. Field trip ke Rumah Sakit

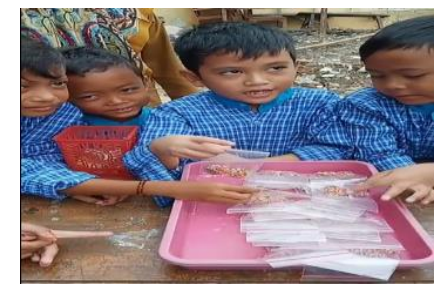

Gambar 4. Kegiatan Market day

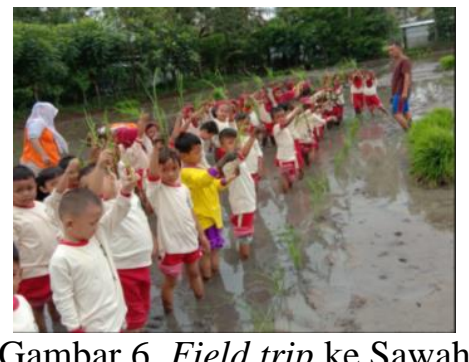

Gambar 6. Field trip ke Sawah

\section{Pembahasan}

Secara keseluruhan penelitian yang dilaksanakan di TK Bona maupun RA Daarul Miqimien sudah ditemukan adanya kegiatan dalam rangka pembelajaran berbasis kewirausahaan dengan masing-masing kekhasannya. "Hari Pasar" dan "Hari Santri" yang ada di TK Bona merupakan kegiatan dalam rangka pembelajaran kewirausahaan dan kecakapan hidup juga bermanfaat untuk mengembangkan aspek perkembangan anak usia dini lainnya, yaitu:

1. Aspek nilai Agama dan Moral: menumbuhkan cinta Tuhan YME, toleransi, dan nilai-nilai kebaikan lainnya.

2. Aspek Sosial-Emosi; menumbuhkan rasa percaya diri, berani, mandiri, dan tanggung jawab. 
3. Aspek Bahasa; menambah kosa kata dengan mengenal nama-nama makanan, dan berlajar berkomunikasi dengan mempromosikan makanannya.

4. Aspek Motorik; mengembangkan motorik kasar maupun halus, dengan memegang makanan atau membantu membuat dan mempersiapkan makanan yang akan dijual.

5. Aspek kognitif; anak mengenal angka terutama angka seribu, dan juga mengetahui berapa jumlah kartu uang yang di butuhkan untuk membeli makanan yang mereka inginkan. Dan pengetahuan akan kehidupan di pesantren sebagai kearifan lokal

6. Kreativitas; kreativitas nampak pada bagaimana anak-anak menyajikan makanan dan promosi yang hendak dijual.

Hasil temuan observasi dan pengelolaan data menunjukkan kegiatan "Hari Pasar" dan "hari santri" sudah cukup baik dalam rangka mengembangkan jiwa kewirausahaan pada anak, akan tetapi masih kurang efektif dikarenakan terdapat beberapa kekurangan diantaranya:

1. Makanan yang di perjual-belikan bukan budaya lokal, sehingga masih banyak anak yang tidak menyukai dan tidak mengenal makanan lokal khas provinsi Banten.

2. Uang yang digunakan bukan uang asli, akan tetapi kartu yang dibuat uang nominal 1000 atau setara dengan Rp.1000, 00. Sehingga anak belum bisa melakukan tukar/kembalian, karena jajanan pun di bandrol harga seribu dan dua ribu

3. Kegiatan hari pasar dan hari santri belum dilaksanakan sesuai dengan tema pembelajaran yang berlangsung pada minggu tersebut.

4. Barang yang diperjual-belikan hanya makanan kesukaan anak-anak, padahal bisa dikembangkan dengan barang lainnya yang dibutuhkan anak misalnya kebutuhan akan pakaian.

5. Pengelolaan lingkungan belajar kewirausahan masih kurang menarik.

6. Penanaman kewirausahaan pada anak usia dini lebih kepada penanaman jiwa atau nilainilai kewirausahaan, seperti sikap tangguh, jujur, kreatif, bertanggung jawab, pekerja keras dan lain-lain, bukan hanya sekedar kegiatan jual beli. Untuk itu kegiatan dalam rangka penanaman jiwa kewirausahaandapat dilakukan dengan kegiatan lain yang lebih bervariasi dan berbasis kearifan lokal.

Kegiatan market day, cooking day maupun Fileld trip yang diselenggarakan di RA Daarul Muqimien merupakan kegiatan dalam rangka menanamkan mental wirausaha pada anak. Selain itu kegiatan tersebut juga dapat mengembangkan aspek perkembangan anak, yaitu moral dan agama, fisik motorik, kognitif, bahasa, sosial-emosi, dan seni-kreativitas. Dalam kegiatan market day dan cooking day, kegiatan memasak dapat mengembangkan kemampuan motorik, percakapan saat menjual selain itu untuk mengembangkan kemampuan Bahasa juga dapat mengembangkan sosial-emosi seperti bersabar menawarkan dagangannya sehingga memiliki mental yang tangguh, mampu mengendalikan diri, dan lain-lain. Kreativitas juga nampak saat anak menghias masakannya agar menarik dan laku saat dipasarkan.

Kegiatan field trip ke mini market, dengan modal uang sepuluh ribu anak dibiarkan memilih belanjaan dan membayarnya sendiri di kasir. Dengan kegiatan tersebut nampak upaya mengembangkan kemampuan sosial-emosi, yaitu dengan bertransaksi dan berinteraksi dengan orang lebih dewasa tanpa didampingi orangtua, memungkinkan anak menjadi pribadi mandiri dan bertanggung jawab untuk memilih belanjaan yang harganya tidak lebih dari sepuluh ribu. Tidak hanya mengembangkan sosial-emosi kegiatan tersebut juga mengembangkan kemampuan kognitif yaitu mengenal nilai rupiah dan angka. Pembelajaran berbasis wira usaha di RA Daarul muqimien terintegrasi dengan tema kegiatan dan holistik mengembangkan tugas perkembangan. Mengunjungi stasiun misalnya, kegiatan ini disesuiakan dengan tema kendaraan. Dengan berkunjung ke rumah sakit, anak diperkenalkan dengan profesi dan prilaku hidup sehat. Field trip ke sawah selain mengembangkan fisik motorik anak dengan kegiatan bercocok tanaman padi juga mengenalkan anak pada kearifan lokal.

Pembelajaran berbasis kearifan lokal di TK Bona Nampak pada kegiatan "nyantri" atau mondok dipesantren, dimana memang di Kota Serang banyak terdapat pondok-pesantren dan anak diharapkan dapat mengetahui dan terbiasa dengan pesantren. Kearifan lokal yang dilaksanakan di RA Daarul Muqimien market day dengan mengunjungi mini market dan 
menjadikannya sebagai sumber belajar yang diselenggarakan di RA Daarul Muqimien, kegiatan field trip ke sawah dan menanam padi, memanfaatkan Rumah sakit di sekitar lingkungan sebagai sumber belajar untuk mengenalkan salah satu profesi, penanaman hidup sehat, dan praktik menjadi dokter. Kegiatan tersebut selain menanamkan jiwa kewirausahaan juga memanfaatkan kearifan lokal. Ini sesuai dengan Permendikbud 137/2014 \& 146/2014 tentang Standar dan Kurikulum PAUD, dimana kegiatan pembelajaran anak usia dini dilaksanakan dengan memanfaatkan potensi, kondisi, dan daya dukung yang dimiliki atau ada dilingkungan lembaga (kearifan lokal).

Beberapa kegiatan dalam rangka menanamkan jiwa kewirausahaan tersebut baik di TK Bona maupun di Ra Daarul Muqimien belum maksimal dalam mengenalkan budaya lokal yang ada di provinsi Banten. Misalnya mengenalkan makanan khas, pada kegiatan market day dan cooking day makanan yang dibuat atau makanan yang dijual lebih pada makanan modern dan makanan yang banyak disukai anak dari pada makanan tradisional. Padahal memperkenalkan anak pada budaya lokal dapat menumbuhkan kecintaan pada bangsa ini. Mengenalkan budaya pada anak juga dapat menjaga kelestarian budaya sehingga memperkuat karakter bangsa. Selain itu juga sesuai dengan Permendikbud 137/2014 \& 146/2014 tentang Standar dan Kurikulum PAUD, yakni penerapan kurikulum PAUD dilaksanakan sesuai dengan karakteristik, potensi, kondisi dan daya dukung yang dimiliki secara optimal. Kegiatan dalam rangka penanaman jiwa kewirausahaan ini juga tampak dilaksanakan dengan perencanaan yang kurang maksimal, karena belum teramati dalam program tahunan ataupun program semester yang dimiliki lembaga dan SOP pelaksanaan pembelajaran.

\section{Simpulan dan Saran}

Penelitian dilaksanakan di dua TK yaitu TK Bona kota Serang dan RA Daarul Muqimein kabupaten Tangerang. Kesimpulan hasil penelitian ini sebagai berikut: TK Bona dan RA Daarul Muqimien telah melaksanakan pembelajaran berbasis kewirausahaan kearifan lokal. Pelaksanaan pembelajaran di TK Bona dilakukan melalui kegiatan yang disebutnya "hari pasar", yang dilaksanakan tiap dua minggu sekali. Dan hari santri yang dilaksanakan menjelang akhir tahun untuk kelas B, yaitu "mondok" atau bermalam dipesantren. Di RA Daarul Muqimien pelaksanaan pembelajaran kewirausahaan melalui kegiatan market day, cooking day, dan field trip dengan memanfaatkan kearifan lokal. Kegiatan tersebut merupakan upaya dalam rangka penanaman jiwa-jiwa kewirausahaan seperti yang tercantum dalam misi RA Daarul Muqimien.

Hasil temuan menunjukan ke dua lembaga sudah melakukan pembelajaran berbasis kewirausahaan akan tetapi masih kurang dalam mengenalkan budaya lokal. Untuk itu perlu diadakan penelitian selanjutnya untuk mengembangkan model pembelajaran anak usia dini berbasis kewirausahaan budaya lokal. Besar harapan penulis penelitian ini dapat dijadikan acuan untuk penelitian tersebut

\section{Daftar Rujukan}

Hamdani dan Rizal, Syamsul. (2019). Kewirausahaan. Ponorogo. Uwais Inspirasi Indonesia. Huliyah, Muhiyatul. (2019). Pendidikan Entrepreneurship pada Anak Usia Dini. Menggagas Arah Baru PAUD di Indonesia, Telaah atas Kesejahteraan dan Kesetaraan Guru serta Lembaga PAUD Formal maupun Non Formal. Prosiding The $4^{\text {th }}$ Annual Meeting and Conference Association of Indonesian Islamic Kindergarten Teachers Education Study Program. Bengkulu, 11-13 April 2019.

Huliyah, Muhiyatul. (2020). Konsep Dasar Pendidikan Anak Usia Dini. Serang: YPSIM Banten.

Mulyasa, E. (2012). Manajemen PAUD. Bandung:Rosdakarya.

Nurseto, Tejo. (2010). Pendidikan Berbasis Entrepreneur. Jurnal Pendidikan Akuntansi Indonesia. Program Studi Pendidikan Akuntasi. Fakultas Ekonomi Universitas Negeri Yogyakarta.

Permendikbud 137/2014 \& 146/2014 tentang Standar dan Kurikulum PAUD 
Rapanna, Patta. (2016). Membumikan Kearifan Lokal Kemandirian Ekonomi. Makasar: Cv Sah Media.

Santrock, John W. (2006). Life Span Development. Alih Bahasa Achmad Chusairi, Jilid 1, Edisi Kelima, Jakarta : Erlangga.

Soemanto, Wasty. (2008). Pendidikan Wiraswasta. Jakarta: PT. Bumi Aksara.

Sugiyono. (2006). Penelitian Pendidikan, Pendekatan Kuantitatif, Kualitatif, dan R\&D. Bandung: Alfabeta.

Sujiono, Yuliani Nurani. (2009. Konsep dasar Pendidikan Anak Usia Dini. Jakarta: PT Indeks.

Suryana, Yuyus \& Bayu, Kartib. (2011). Kewirausahaan Pendekatan Karakteristik Wirausahawan Sukses. Jakarta: Prenada media Group. 